\title{
Uptake of Uranium by Various Cell Fractions of Chlorella regularis ${ }^{\dagger}$
}

\author{
Takao HoRIKOSHI, Akira NAKAJIMA and Takashi SAKAgUCHI \\ Department of Chemistry, Miyazaki Medical College, Kiyotake, Miyazaki 889-16 \\ Received April 25, 1979
}

\begin{abstract}
To know what kinds of the cell components of Chlorella regularis are concerned with uranium binding, uptake of uranium by various cell fractions was examined. The uptake value ( $\mu \mathrm{gU} / \mathrm{mg}$ starting dry cells) of the hot water-treated cells was almost the same as that of the starting dry Chlorella cells, showing that the cell components extracted with hot water were not so concerned with uranium binding. The cell components extracted with dilute alkali seemed to play an important role in uranium binding, and those extracted with chloroform-methanol seemed to be partly concerned with uranium binding. The cellulose fraction of the cells was scarcely concerned with uranium binding. In the dry cells, $34 \%$ of uranium taken up existed in the cell walls. However, in the living cells, 85\% existed in the cell walls. The above results showed that the dry or the hot water-treated cells are the most convenient for uranium recovery from the aqueous systems.
\end{abstract}

Key Words: uranium uptake, cell fractions, Chlorella

\section{Introduction}

We have been studying the recovery of uranium from the aqueous systems by microal$\mathrm{gae}^{1)-4)}$ : (1) Chlorella regularis, one of the fresh-water green microalgae, could take up a relatively large amount of uranium from the solution containing uranium only; (2) scalded (treated in boiling water for $5 \mathrm{~min}$ ) Chlorella cells could take up 3 times more uranium than the living cells; (3) the most part of the uptake of uranium was not directly mediated by metabolic processes, but depended upon physicochemical adsorption on the cell surface. However, little is known about the cell components which are concerned with uranium binding. In this paper, to know what kinds of the cell components are concerned with uranium binding, the uranium uptake by the cells treated with hot water, dilute alkali, concentrated alkali, or chloroform-methanol and by the cell wall material was examined.

† Studies on the Accumulation of Heavy Metal Elements in Biological Systems (Part XIII).

\section{Materials and Methods}

2.1 Cultivation of Chlorella

Chlorella regularis $\mathrm{S}-50^{1)}$ was grown in a $20 l$-bottle containing $20 l$ mineral salts-urea medium $^{5)}$ with aeration at $30^{\circ} \mathrm{C}$. The bottle was illuminated continuously by white fluorescent lamps giving a light intensity of 4,400-4,800 lux at the surface of the bottle. After 6 days, the cells in the linearly growing phase were collected by centrifugation at $6,000 \times g$ for $5 \mathrm{~min}$, washed thoroughly with deionized water, and then freeze-dried.

2.2 Preparation of the chemically treated cells and the cell wall materials

(i) Hot water-treated cells. One gram dry cells of Chlorella was treated with $100 \mathrm{~m} l$ of deionized water at $100^{\circ} \mathrm{C}$ under reflux. After $2 \mathrm{hr}$, the cells were collected by centrifugation, washed thoroughly with deionized water, and freeze-dried. The yield was $670 \mathrm{mg}$ on a dry weight basis. (ii) Dilute alkali-treated cells. The dry cells $(1 \mathrm{~g})$ were treated with $100 \mathrm{~m} l$ of 
$0.2 \% \mathrm{NaOH}$ solution at room temperature with continuously stirring. After $20 \mathrm{hr}$, the green residue was collected by centrifugation, washed thoroughly with deionized water, and then freeze-dried (yield on a dry weight basis, 470.8 $\mathrm{mg}$ ). (iii) Chloroform-methanol treated cells. The dry cells $(2 \mathrm{~g})$ were treated with $100 \mathrm{~m} l$ of aq. $96 \%(\mathrm{v} / \mathrm{v})$ methanol at $65^{\circ} \mathrm{C}$ under reflux. After $10 \mathrm{~min}$, the solution was cooled to room temperature, and $200 \mathrm{~m} l$ chloroform was added. The chloroform-methanol mixture was stirred at room temperature for $20 \mathrm{~min}$. After centrif ugation, the cells treated with chloroformmethanol was retreated with further $100 \mathrm{~m} l$ of chloroform-methanol (2:1) for $20 \mathrm{~min}$, centrifuged and dried. The yield of the pale-green residue was $1,413.7 \mathrm{mg}$. (iv) Chloroform-methanol/concentrated alkali-treated cells. Chlorella cells $(700.5 \mathrm{mg}$ dry wt.) treated with chloroformmethanol as in (iii) was treated with $100 \mathrm{~m} l$ of $24 \%(\mathrm{w} / \mathrm{v}) \mathrm{KOH}$ at room temperature under $\mathrm{N}_{2}$ for $2 \mathrm{hr}$ with sometimes shaking. Then the cells were centrifuged and re-extracted with further $10 \mathrm{~m} l$ of $\mathrm{KOH}$ for $2 \mathrm{hr}$. The residue was thoroughly washed with deionized water by suspension and centrifuging, and then freezedried. The yield of white preparation was $137.3 \mathrm{mg}$. (v) The cell wall materials. The dry cells $(15.0 \mathrm{~g}$ dry $\mathrm{wt}$.) were disrupted using the X-press (LKB Co., Sweden) at $2,700 \mathrm{~kg} / \mathrm{cm}^{2}$. The resultant cell homogenate was heated at $100^{\circ} \mathrm{C}$ for $10 \mathrm{~min}$ and centrifuged at $1,000 \times g$ for $10 \mathrm{~min}$. The $1,000 \times g$ precipitate was washed thoroughly with deionized water until the supernatant solution became clear, and freezedried. The yield, $4.637 \mathrm{~g}$. The optical microscope examination showed that few unbroken cells existed in the preparation.

\subsection{Uptake experiments}

The uptake experiments were carried out using $1 l$ Erlenmeyer flasks containing $500 \mathrm{~m} l$ of the uptake solution containing uranium only. Uranium was supplied as $\mathrm{UO}_{2}\left(\mathrm{CO}_{3}\right)_{3}{ }^{4-}$ form ${ }^{6}$ to make the final uranium concentration $4 \mathrm{ppm}$. The $\mathrm{pH}$ value of the uptake solution was adjusted to 8 with $0.1 \mathrm{~N} \mathrm{HCl}$ solution. Twenty $\mathrm{mg}$ of the dry cells, the chemically treated cells, and the cell wall materials were suspended in the uptake solution at $30^{\circ} \mathrm{C}$ with continuously stirring. After $30 \mathrm{~min}$, the cells and the cell wall materials were collected by filtration through Millipore filter (pore size, $0.22 \mu \mathrm{m}$ ), washed thoroughly with deionized water, and then freeze-dried.

2.4 Determination of uranium in the cells and the cell walls

The amount of uranium taken up was determined by neutron activation analysis utilizing the gamma ray delivered from ${ }^{239} \mathrm{U}$. The detailed method of the activation analysis was described previously? ${ }^{7}$.

\section{Results and Discussion}

The uranium uptake values of the chemically treated cells and the cell wall materials were expressed as $\mu \mathrm{g}$ of uranium per $\mathrm{mg}$ of the starting dry cells correcting the loss of dry weight by each treatment. The results are shown in Table 1. The uptake value of the hot watertreated cells was almost the same as that of the dry cells. This showed that the cell components extracted with hot water (oligo- and polysaccharides, proteins, and many low molecular weight substances) were not so concerned with uranium binding.

The uptake value of Chlorella cells treated with chloroform-methanol was $73 \%$ of that of the dry cells, showing that the cell components extracted with chloroform-methanol (mainly lipids) seemed to be partly concerned with uranium binding. But the possibility of the denaturation of the ligands for uranium binding by the chloroform-methanol treatment was present.

In the case of the dilute alkali-treated cells, the uptake value was only $53 \%$ of that of the dry cells. This result suggested that the cell components extracted with dilute alkali (proteins, polysaccharides, etc.) played an important role in uranium binding. However, it was possible that the denaturation of the ligands for uranium binding by the dilute alkali treatment seemed to lead to the lowering of the uptake capacity.

The uptake value of the cells treated with chloroform-methanol/concentrated alkali was very small, showing that this fraction (mainly 
Table 1 Uptake of uranium by various cell fractions of Chlorella regularis

\begin{tabular}{l|l|c|c}
\hline \multicolumn{2}{c|}{ Cell fractions } & $\begin{array}{c}\text { Yields in treatments to } \\
\text { the starting whole dry } \\
\text { cells (\%) }\end{array}$ & $\begin{array}{c}\mu \mathrm{gU} / \mathrm{mg} \text { of starting } \\
\mathrm{dry} \text { cells }\end{array}$ \\
\hline \multicolumn{2}{l|}{ Whole dry cells } & 100.0 & $37.3(100.0)$ \\
\hline \multirow{3}{*}{$\begin{array}{l}\text { Chemically } \\
\text { treated cells }\end{array}$} & Hot water-treated & 67.0 & $37.4(100.3)$ \\
\cline { 2 - 4 } & Chloroform-methanol-treated & 70.7 & $27.2(72.9)$ \\
\cline { 2 - 4 } & $\begin{array}{l}\text { Dilute alkali-treated } \\
\text { alkali-treated }\end{array}$ & 47.1 & $19.8(53.1)$ \\
\hline Cell walls & & 13.9 & $0.7(1.9)$ \\
\hline Living cells & 30.9 & $12.6 *(33.8)$ \\
\hline
\end{tabular}

Cell amounts used were $20 \mathrm{mg}$ except for the living cells $(15.6 \mathrm{mg})$. Values in parentheses are expressed as per cent of the value of the dry cells.

$* \mu \mathrm{gU} / \mathrm{mg}$ dry wt..

cellulose) was scarcely concerned with uranium binding.

The uptake value of the cell wall materials was only $34 \%$ of the uptake value of the dry cells. This result indicated that in the dry cells the intracellular components participated in uranium binding and these intracellular components were removed during the preparation of the walls. Furthermore, the uptake value of the cell walls was about $85 \%$ of that of the living cells, suggesting that the cell wall materials played an important role in uranium uptake by the living cells. This result was consistent with our previous observations ${ }^{1)}$ that $75-80 \%$ of uranium taken up by the living cells was adsorbed on the cell surface.

From the above results we concluded: (a) in the dry cells the cell components extracted with dilute alkali (proteins, polysaccharides, etc.) seemed to play an important role in uranium binding; (b) in the living cells $85 \%$ of uranium taken up existed in the cell walls; (c) the dry or the hot water-treated cells are the most convenient for uranium recovery from the aqueous systems.

\section{Acknowledgement}

We wish to thank Dr. F. Shiraishi of the Institute for Atomic Energy of Rikkyo University for his kind help with the neutron activation analysis.

\section{References}

1) T. Horikoshi, A. Nakajima and T. Sakaguchi: Agric. Biol. Chem., 43, 617 (1979)

2) A. Nakajima, T. Horikoshi and T. Sakaguchi: ibid., 43, 625 (1979)

3) T. Sakaguchi, T. Horikoshi and A. Nakajima: J. Ferment. Technol., 56, 561 (1978)

4) T. Horikoshi, A. Nakajima and T. Sakaguchi: ibid., 57, 191 (1979),

5) T. Sakaguchi, T. Horikoshi and A. Nakajima: J. Agric. Chem. Soc. Japan, 51, 497 (1977)

6) N. Ogata: J. Atomic Energy Soc. Japan, 10, 672 (1968)

7) T. Sakaguchi, A. Nakajima and T. Horikoshi: J. Agric. Chem. Soc. Japan, 53, 211 (1979) 
要旨

\title{
種々のクロレラ藻体画分によるウランの取込み†
}

\author{
堀越孝雄, 中島 睴, 坂口孝司 \\ 宮崎医科大学医学部化学教室
}

889-16 宮崎県宮崎郡清武町木原5200

\begin{abstract}
クロレラ藻体中のどのような成分がウランの取込みに関与しているかを調べるために，種々のク ロレラ藻体画分のウラン取込み能について検討した。その結果，希アルカリによって抽出される成 分はウラン取込みに重要な役割を果しており,クロロホルムーメタノールによって抽出される成分る ウラン取込みに若干関与しているが，熱水によって抽出される成分およびセルロース画分はウラン の取込みにほとんど関与していないことが明らかになった。一方，細胞壁に取り込まれたウランの 量は, 乾燥全藻体の取込み量の34\%，生藻体による全取込み量の $85 \%$ に相当することがわかった。 以上の結果から，水圏中のウラン回収には乾燥藻体, 熱処理藻体を用いると最も効率がよいことが 明らかになった。
\end{abstract}

†重金属元素の生体濃縮に関する研究（第13報） 